\title{
APPEARANCES BY LAYMEN IN A REPRESENTA- TIVE CAPACITY BEFORE ADMINISTRATIVE BODIES
}

\author{
WM. Hedges Robinson, JR.*
}

One of the most controversial of the questions raised by the problem of unauthorized practice concerns the appearance by laymen in a representative capacity before boards, bureaus, commissions, and other quasi-judicial bodies, because the solution depends more upon factors which are embodied in the economic and social structure than upon any particular definition of what may or may not constitute the practice of law. The answers which have been given to the question have not afforded universal satisfaction, nor is the answer the same in all of the different jurisdictions. Public policy as defined by the legislature, as well as the socio-political opinion of a judge, has led to varying opinions.

To find a satisfactory solution requires an approach based upon a realization that the problem is not engendered by lawyers and practitioners-as I shall denominate the lay group - bickering over fees. This incidental feature, which may be so played upon as to seem the real issue, is an unfortunate offshoot. In reality, the solution requires coalition of three points of view: first, that of the public; second, that of the lawyer; and third, that of the practitioner. While the interest of the public must be considered of paramount importance, any answer which places undue emphasis upon any one of these points of view, or which ignores one, will probably prove unsatisfactory.

Therefore, an analysis which takes cognizance of all of these points of view should be made of the answers to this question. Three distinct answers have been offered: first, some states hold that any person may practice before any board or quasi-judicial body. ${ }^{1}$ This attitude proceeds upon a very limited construction of what constitutes the practice of law. Any board, department, bureau, or commission which is not a court in the strict sense is not a judicial body, according to these opinions, but a branch of the executive department. Hence, laymen may appear before these

* A.B., LL.B., 1931, LL.M., 1932, University of Colorado. Member of the Colorado Bar, practicing in Denver. Editor, Dicta. Instructor, Westminster Law School. Formerly Assistant to the Director of the National Bar Program of the American Bar Association. Contributor to legal periodicals.

${ }^{1}$ North Dakota is probably such a state. There are no statutes forbidding such practice and the Supreme Court has taken a very restricted view of its powers over unauthorized practice of law. Murphy v. Townley, 274 N. W. 857 (N. D. I937). In general, see cases collected in' Hicks \& Katz, UNAUTHOrizED Practice of Law (r934) 69, and Brand, Unauthorized Practice Decisions (x937) 783 . 
tribunals as "agents" or "attorneys in fact" for clients. These decisions overlook the accepted theory of administrative law that these bodies are part judicial in their nature. It shoud be pointed out, however, that in some instances these states have statutes which so define "practice of law" as to exclude therefrom appearances before administrative bodies, or which expressly authorize laymen to appear before the administrative board created by the statute.

This approach to the problem takes into account only the point of view of the practitioner. No safeguard is provided for the interest of the public. It permits untrained individuals bound by no code of ethics, and unhampered by any disciplinary supervision, to engage in the business of representing claimants. All of the evils of champerty, maintenance, and unethical practice may flourish without restraint. Any unscrupulous individual, any disbarred attorney, any ignoramus may be a practitioner under this doctrine, for there are no standards of ethics or of education, nor is any method of discipline provided. In addition to failing to protect the welfare of the public, this answer forces men who have spent years in formal training to acquire the skill to practice law to compete with individuals who may be utterly lacking in formal education or acceptable norms of conduct. Lawyers, who are unable to advertise or solicit business, are opposed by laymen who often actively solicit business in the broadest sense of the phrase. This is unfair competition of the worst kind and is decidedly an unhealthy condition not only for the bar, but for the public.

The public in the very early days of this nation was faced with the same problem in regard to lawyers, for admission to the bar was a mere formality. But as public rights began to receive recognition, it was seen that some curb must be placed upon the so-called rights of the individual. Hence, standards of education, conduct, and ethics were imposed upon those who desired to become lawyers, and these standards were continually raised; for it came to be recognized that the practice of the law was affected with a public interest and that it was both the right and the duty of the state to regulate and control it so that public welfare would be served and promoted.

Hence, this first answer should be disregarded by all concerned, for it is harmful to the public, unfair to the lawyer, and unsatisfactory to the qualified practitioner. The lesson taught by the revolts against the untrained lawyers in Colonial New England should be heeded by those practitioners who continue to urge that no restraint should be placed upon their practice. No system can survive built upon a foundation which is fundamentally opposed to the public welfare, nor can the first answer be accepted permanently even if attempts are made to have the various boards and bureaus prescribe individual standards of admission and ethics. Such a solution can at the most be only a makeshift one. The federal government has attempted this solution only to find that it has resulted in chaos. ${ }^{2}$

Since July 4, 1894, the United States Government has made some scattered and unrelated attempts to deal with this problem. It has a host of boards, bureaus, and

\footnotetext{
${ }^{2}$ See Robinson, Lawyers and Practitioners: A Study in Contrasts (1935) 21 A. B. A. J. 277, for a more detailed discussion of the federal situation.
} 
commissions, each of which has its own special rules regarding the admission to practice before them. In general, they may be grouped into two main divisions. The first group, of which the Bureau of Pensions is a fair example, permits any person to practice before it if an application is made, an oath is taken, and a certificate as to character, reputation, and general fitness is furnished. The second group, of which the Board of Tax Appeals is outstanding, admits only licensed attorneys or qualified public accountants to practice before it. The first group of administrative bodies provides little, if any, method for disciplining its practitioners; and as a result, laymen, without any particular educational qualifications or training, and without any conception of ethics, run rampant. On the other hand, the second group has provided elaborate methods to discipline the practitioners. The Treasury Department, for example, lists numerous grounds for invoking disciplinary measures and provides for a hearing before established divisions within the department. Unfortunately, however, this elaborate machinery is seldom used. Disbarment from one commission or bureau of the federal government will not, moreover, disbar one from practice within other divisions of the same department, even less from other departments. It will thus be seen that the federal picture is even more chaotic and confusing than that existing in those states which have set the administrative bodies to drift as they pleased so far as regulations over admissions and discipline of the practitioners are concerned.

The second answer to our problem states that laymen may appear before the quasi-judicial tribunals only so long as their work does not involve the necessity for special legal skill and training. What may or may not constitute an encroachment is left for judicial definition in each case. Thus, in Pennsylvania, the court in the case of Shortz v. Farrell ${ }^{3}$ permitted the practitioner to prepare and file pleadings in workmen's compensation cases, because the "pleadings" are "executed on forms prepared by the board, are elementary in character, and do not rise to the dignity of pleadings as that term is understood in other judicial proceedings." But this court expressly enjoined laymen from appearing before the referee in a representative capacity.

Under a recent Ohio decision, Goodman v. Beall, ${ }^{4}$ laymen may prepare pleadings and appear in a representative capacity before the State Industrial Commission on the original hearing. However, "rehearing proceedings before the commission do constitute the practice of law and must be conducted exclusively and personally by an attorney or attorneys at law, duly admitted to practice." Under the Ohio statute, the record made at the rehearing becomes the basis for "an appeal" to the court of common pleas; and the decision of the court on this appeal is limited to the evidence submitted at the rehearing.

The answer proposed by this group of decisions is likewise unsatisfactory. It is open to the objections urged against the first answer, namely, that the interests of

\footnotetext{
${ }^{3} 327$ Pa. 8r, 193 Atl. 20 (1937).

I30 Ohio St. 427,200 N. E. 470 (1936); cf. State ex rel. Juergens v. Industrial Commission, 127 Ohio St. 524, I 89 N. E. 445 (1934); Dunlap v. Lebus, I12 Ky. 237,65 S. W. 44 I (Igor).
} 
the public and lawyers are not protected due to the lack of standards of ethics and education. No control over the practitioner is left to the public. However, the answer is undoubtedly more fair to the lawyer for it separates certain functions from what may constitute the practice of law, permitting the practitioner to practice within the segregated sphere, while restricting him from invading certain defined preserves which constitute the practice of law.

But this answer creates an unsettled condition engendered by the uncertainty as to what particular sphere is open to the practitioner until there has been a judicial determination. In other words, a judicial decision is necessary to define what constitutes the practice of law in so far as every particular board, bureau, commission, or department is concerned, and these decisions may vary as much as the individual temperament of the judge deciding the case. It is no answer to say that the legislature in the creation of these administrative bodies can outline what constitutes the practice of law in each particular instance, for the courts have uniformly held that the judicial branch of government alone has the inherent right to determine what constitutes unauthorized practice and to control those admitted to the bar. ${ }^{5}$ In addition, the same unstable level exists whether the legislature or judicial department of the government attempts to draw the boundary line. It is hardly an answer which can be accepted by the practitioner for he is left dangling in the realm of uncertainty as to what he may legitimately do and is given no protection from the unscrupulous acts of his associates.

There can be no doubt that a small minority of practitioners desire that certain very definite standards be imposed upon the group for they are aware that to permit any person to become a practitioner is injurious to those who are sincerely attempting to represent clients before administrative bodies in a professional manner. There also can be no doubt that a small group of practitioners are as well if not better trained and qualified to act before these quasi-judicial boards than are most lawyers. To deny the trained practitioner the right to appear often works an injustice to him and to those who would be his clients, and in the broad sense is not for the best interest of the public.

The third answer permits only lawyers to practice before the quasi-judicial bodies. This solution is apparently accepted in Illinois, Michigan, Missouri, and perhaps New York. The court in Illinois ${ }^{6}$ found this answer by the following process of reasoning:

"Administrative law, although of comparatively recent growth, is recognized today as an important branch of the law. Classes for the study thereof are now taught in many of our leading law schools. Relatively speaking, not many years ago that part of a legal education was unknown to the curriculums of law colleges. In addition to the rigid educational requirements, the applicant must possess a good moral character. These prerequisites are not for the purpose of creating a monopoly in the legal profession nor for its

'See, e. g., In re Opinion of the Justices, 289 Mass. 607, I94 N. E. 313 (1935).

- Pcople ex rel. Chicago Bar Ass'n v. Goodman, 366 Ill. 346, 353, 8 N. E. (2d) 941, 944 (1937); State Bar v. Waldron (Dist. Ct., Okla. I935), BRAND, op. cit. stspra note 1 , at 442 . 
protection, but are for the better security of the people against incompetency and dishonesty."

"It is elementary that a great portion of the present-day practice of law is conducted outside the courtroom. The respondent urges that because the legislative act relating to the Industrial Commission grants to that body the right to promulgate rules governing the procedure before it, and the commission has adopted a rule permitting a party to appear before it by his attorney or 'agent,' he, as agent of the claimant, may lawfully appear before the commission as the representative of the client and try his claim there. Even though the Industrial Commission is merely an administrative body, yet, if what the respondent did for a fee, in the presentation of and hearing of a practitioner's claim before that body, amounted to the practice of law, a rule of the commission purporting to grant him that privilege is of no avail to him. The General Assembly has no authority to grant a layman the right to practice law. It follows that any rule adopted by the commission, purporting to bestow such privilege upon one not a duly licensed attorney at law, is void. Nor can the General Assembly lawfully declare not to be the practice of law, those activities the performance of which the judicial department may determine is the practice of law."

The Illinois court distinguishes the basis for its reasoning from Goodman v. Beall on the ground of the particular statutes involved in each state, pointing out that the proceedings on rehearing in Ohio correspond with the allowance of claims by the commission on the original hearing in Illinois.

In Michigan, however, a circuit court has made no attempt to distinguish between any statutes which may be involved. In the case of Michigan State Bar v. McGregor, ${ }^{8}$ decided in 1935 , the court simply stated:

"It is urged that the Department of Labor is not a court but an administrative body and all acts done before it or in connection with it are outside the practice of law. True the Department of Labor and Industry is not a court. But the doctrine of res adjudicata applies to its proceedings and its decisions are binding upon all parties when not appealed from.

"It is a matter of common knowledge and a fact of which the court may take judicial notice, that the Department of Labor and Industry, acting through its commissioners sitting as a board, and through its deputy commissioners, holds hearings throughout the state which are conducted under well defined and printed rules; considers legal questions, applies legal principles and weighs facts under legal rules. Litigating parties appear before deputy commissioners and before the full board by attorneys almost as universally as they do in courts of record. Practice before this board is an extensive branch of the law business."

\footnotetext{
${ }^{7}$ Supra note 4. If the decision is actually based upon this ground, Illinois properly belongs in the second group. But the distinction between the statutes involved does not seem to be the true basis. If it is, then the dissenting opinion of Justice Shaw, which is based upon lack of inherent power of the court, would seem to arrive at the correct legal solution; for if the court has no power to regulate practice and to define it, then the matter must be left for statutory control.

${ }^{8}$ Brand, op. cit. supra note 1 , at 258; cf. Clark v. Austin, Ior S. W. (2d) 977 (Mo. 1937); Mandelbaum v. Gilbert \& Barker Mfg. Co., 160 Misc. 656, 290 N. Y. Supp. 462 (1936); Elfenbein v. Luckenback Terminals, Inc., III N. J. L. 67, 166 Atl. 91 (1933). For a discussion based upon the Missouri case, see Howard, Control of Unauthorized Practice before Administrative Tribunals in Missouri (1937) 2 Mo. L. REv. 313 .
} 
The Michigan court is not unmindful, however, of the fact that in some cases the practitioner may be better qualified to practice than the average lawyer. While the result reached in the particular case may not be the best so far as it pertained to this defendant, yet the court properly felt itself without the power to give any decision which would differentiate between the abilities and qualifications of the practitioners.

The answer given by this third group is not entirely acceptable. It unduly protects the lawyers as against the practitioners, and fails to recognize that in the field of administrative law a practitioner may more effectively and ably deal with the problems than a lawyer. Therefore, the interest of the public is served in part and denied in part by this solution.

Consequently, it would seem best to disregard all of these answers. They all have certain fundamental objections which cannot be eradicated by legislative meddling or judicial tinkering. The approach to a solution should be based upon a recognition that administrative law is definitely grafted onto present governmental structures, and that it fulfills a need which the courts at present are neither equipped nor trained to satisfy. Since these administrative bodies are an accepted part of government, it is certain that they will within a few years acquire a formality which is now lacking to a large extent and that untrained litigants will be forced to demand representation before them. Practitioners are then inevitable. Merely because of this fact, it is not wise to open wide the portals to all who desire to act in a representative capacity, nor to attempt to apply exactly the same requirements to these practitioners which are now applied to lawyers.

While it is true that the enormous development in recent years of administrative boards and tribunals has made for haphazard and arbitrary rules, yet there is no reason to apply to these bodies the identical principles and philosophy which have been applied to the courts, for if that is to be, administrative law loses its effectiveness and would better be administered by the law courts. So, too, it would be unwise to apply exactly the same standards to the practitioners as to the lawyers. No doubt a uniform standard of ethics can well be adopted by both groups; but an attempt to apply exactly the same training to the practitioner as required of the lawyer, or to demand that the lawyer be trained as a practitioner should be trained will result in wasted effort.

It would seem that the ultimate solution of this troublesome question requires more than an attempt to formulate an all-inclusive definition of what constitutes the practice of law. It requires a complete overhauling of that Gargantuan growth which has been termed administrative law. New concepts, an effort for co-ordination, a period of readjustment are among those things which are vitally needed to work out this problem.

The only feasible solution yet to be advanced pertains to the federal government, but it is easily adaptable to the state governments. The plan provides that the quasijudicial bodies be consolidated into an administrative tribunal divided into depart- 
ments. ${ }^{9}$ The judges of this court would be composed of the experts who are the heads of the now unrelated and uncoordinated administrative bodies. Uniform rules of practice and procedure would exist before all of the various departments of the tribunal.

With the consolidation of these various boards, bureaus, and commissions would come uniform standards for the practitioners. Definite rules for admission to practice and a code of ethics could be promulgated. The inevitable result would be the creation of a practitioners' bar as a recognized branch of the judicial department. This bar would require certain educational standards. These standards might differ radically from those required of the lawyers. More emphasis would no doubt be placed upon technical training in such fields as engineering, accounting, corporate finance, and labor, employer relationships, and less emphasis, or none at all, upon some subjects now studied in law schools such as real property and equity. Yet a certain degree of formal education would be required before application for admission to practice would be accepted.

The educational training for the practitioner would be based on the principles underlying administrative law. It would recognize the need for training in such specialized subjects as have heretofore been believed to be outside the formal education required of a lawyer. The present approach of law schools relating to adjective law would have to be entirely revamped. Our present system of legal education in this field is in many places arbitrary to the point of being despotic, unreasonable to the point of being faintly humorous, and hopelessly out of keeping with the solution of modern problems. The emphasis of the training of the practitioner would be less on the previous rules of evidence, and more upon the development of a practical method of placing all facts before a tribunal in a quick and efficient method. Thus, the education of the practitioner and lawyer would differ greatly-not that the practitioner should be any less trained in his field than the lawyer now is in his; merely that the type of training would be different. The code of ethics naturally would be the same for the lawyer and practitioner, and both could be subject to the same disciplinary machinery.

For all purposes it would seem that the best practical method of correlating the two proposed groups would be to create a bar with two divisions-perhaps three. One division would be for the practitioners, members of which would be limited to practice before the administrative court. The second division would embrace the lawyers practicing before the law and equity courts. A third division (not essential but possible) might be created, open to lawyers of prescribed experience, for practice in the appellate courts on appeals from the administrative, and law and equity courts.

How could this bar be created? The problem is not weighty from a mechanical aspect, although from the standpoint of human relationships it may require considerable time and a vast amount of social adjustment before it can be accomplished. To the writer it seems to comprehend, first of all, a unified court system. This means

\footnotetext{
o 61 Am. Bar Ass'n Rep. (1936) 720. But see Am. Bar Ass'n, Advance Program (1937) i65 at i84.
} 
that the outlined administrative tribunal must be created, and that all courts, including the administrative court, must be made a part of a unified system, supervised and controlled by a supreme court. It also requires a complete reorganization of the bar with provisions made for the divisions suggested above. Probably some form of an integrated or federalized bar association would be a necessary concomitant of this plan of reorganization.

The ideal plan, of course, would be to make a clean-cut two-fold reorganization of the judicial branch of the government, involving the creation of the bar, and of the unified court system. While, because of considerations of "practical politics," it is perhaps impossible to make such a change immediately, yet it would be wise, it seems, for all concerned to urge it lest the bar find itself in the position of the medical societies with their battles between the "old school" and "new school" doctors. The example of the men of medicine squabbling over fields of practice and rights therein should be thoroughly considered by the lawyer and practitioner, for that very sort of thing looms upon our horizons.

As a practical method of evolution, it might be wise to begin by first creating at least a semi-professional group known as practitioners, with the ideal of leading ultimately to the status of a professional body as suggested. As for the court reform, it is a measure that is needed in itself in many states; and, while it is a part of the proposal, steps to bring it about need not wait on the creation of the administrative tribunal. Nor is there any necessity of holding back on either of these proposals until the setting up of a practitioner's bar. A material advance on any of these fronts should bring that much nearer the solution of the problem under consideration. 